\title{
KELANGSUNGAN HIDUP BENIH IKAN PATIN (Pangasius hypophthalmus) PADA SISTEM AKUAPONIK DENGAN KEPADATAN TANAMAN AIR YANG BERBEDA
}

\author{
${ }^{1)}$ Muarofah Ghofur dan ${ }^{2)}$ M.Yusuf Arifin \\ Program Studi Budidaya Perairan, Fakultas Pertanian Universitas Batanghari \\ Jl. Slamet Riyadi, Broni Jambi. 36122. Telp. +62074160103 \\ ${ }^{1)}$ Email : muarofah_ghofur@yahoo.com
}

\begin{abstract}
The purpose of this research is to know the optimum plant density of water for the maintenance offish catfish ( $P$. hypophthalmus) on akuaponik system in order to produce a high fish survival. As for the benefits of this activity is to improve the production results mainlyfrom the fishery commodity fish catfish (P. hypophthalmus). This research plan will be implemented in March and July of 2018 in the porch Area Fish Seed Telanaipura the province of Jambi. Research conducted using Complete Random Design environmental design (RAL) with four (4) treatment and three replicates, each treatment are: A treatment: 5 bar/hole, $B$ treatment: 10bar/hole, the treatment $C: 15$ shaft/hole, D treatment: 20 bar/hole. The research of the parameters observedwere: survival rates of fish and water quality.

Keywords: Aquatic plants, fish catfish, akuaponik
\end{abstract}

\begin{abstract}
Abstrak
Tujuan dari penelitian ini adalah untuk mengetahui kepadatan optimum tanaman air untuk pemeliharaan ikan patin ( $P$. hypophthalmus) pada sistem akuaponik agar dapat menghasilkan kelangsungan hidup ikan yang tinggi. Adapun manfaat dari kegiatan ini adalah untuk meningkatkan hasil produksi perikanan terutama dari komoditas ikan patin ( $P$. hypophthalmus). Penelitian ini dilaksanakan pada bulan Maret sampai bulan Juni tahun 2018 di Balai Benih Ikan Daerah Telanaipura Provinsi Jambi. Penelitian yang dilakukan menggunakan rancangan lingkungan Rancangan Acak Lengkap (RAL) dengan 4 (empat) perlakuan dan 3 (tiga) ulangan, masing - masing perlakuan tersebut adalah : perlakuan A : 5 batang/lubang, perlakuan B : 10 batang/lubang, perlakuan C : 15 batang/lubang, perlakuan D : 20 batang/lubang. Parameter penelitian yang diamati adalah: Tingkat Kelangsungan Hidup Ikan dan Kualitas Air. Hasil penelitian yang diperoleh adalah tingkat kelangsungan hidup ikan patin selama dipelihara dengan system akuaponik sebesar 84,68 persen dan hasil pengukuran kualitas air menunjukkan suhu berkisar antara 28,7-31,5, pH berkisar 5-7, oksigen terlarut sekitar 3-7 mg/L dan karbondioksida 0,345-0,803 mg/L. Sedangkan nitrat sebesar 0,005-0,028 mg/L, nitrat berkisar antara $0,12-0,25 \mathrm{mg} / \mathrm{L}$ dan amoniak sekitar $0,0111-0,033 \mathrm{mg} / \mathrm{L}$.

Kata kunci : tanaman air, ikan patin, akuaponik
\end{abstract}




\section{PENDAHULUAN}

Ikan patin siam (Pangasianodon hypopthalmus F) merupakan ikan potensial bernilai ekonomis tinggi. Produksi perikanan hasil budidaya provinsi jambi tahun 2016 sebanyak 45.265,8 ton dimana Kabupaten Muaro Jambi sebagai pemegang andil terbesar budidaya ikan patin (BPS Provinsi Jambi, 2016). Selain itu Dinas Kelautan dan Perikanan (DKP) Provinsi Jambi telah menargetkan sekitar 54.000 ton ikan budidaya yang tersebar di Kabupaten/Kota Se Provinsi Jambi (Fokus Jambi, 2016).

Inovasi teknologi diperlukan untuk mengantisipasi penurunan produksi akuakultur akibat penyusutan lahan budidaya dan penurunan kualitas perairan. Inovasi teknologi tersebut diharapkan mampu mengurangi limbah dan meningkatkan produktifitas persatuan luas lahan budidaya. Salah satu inovasi teknologi yang diterapkan yaitu budidaya ikan yang terintegrasi dengan tanaman melalui sistem akuaponik. Teknologi akuaponik terbukti mampu berhasil memproduksi ikan secara optimal pada lahan sempit dan sumber air terbatas, termasuk di daerah perkotaan. Teknologi ini pada prinsipnya disamping menghemat penggunaan lahan dan air juga meningkatkan efisiensi usaha melalui pemanfaatan hara dari sisa pakan dan metabolisme ikan untuk tanaman air serta merupakan salah satu sistem budidaya ikan yang ramah lingkungan (Chou, 1994). Akuaponik (aquaphonic) merupakan salah satu teknologi budidaya yang mengkombinasikan pemeliharaan ikan dengan tanaman. Sistem ini dapat menghemat penggunaan air dalam budidaya ikan sampai 97\% (Effendi, 2000).

Interaksi antara ikan dan tanaman pada sistem ini menciptakan lingkungan tumbuh yang lebih produktif dari metode konvensional. Budidaya menggunakan sistem akuaponik lebih ramah lingkungan karena tidak menghasilkan limbah sehingga tidak membahayakan lingkungan (Zero Enviromental Impact) dibandingkan dengan sitem budidaya lainnya. Menurut Chou (1994), sistem akuaponik dapat menghasilkan ikan dan tanaman organik yang berkualitas tinggi, yaitu produk yang terbebas dari zat kimia yang berasal dari penggunaan pupuk buatan, pestisida maupun herbisida. Selain menghemat penggunaan lahan dan air, sistem akuaponik juga meningkatkan efisiensi usaha melalui pemanfaatan hara dari sisa pakan dan metabolisme ikan. Sisa pakan dan hasil metabolisme ikan (feses dan urin) akan menghasilkan limbah berupa ammonia. Ammonia yang terlalu banyak dalam wadah budidaya akan menjadi racun bagi ikan. Menurut Forteath (1993), pada sistem akuaponik, bakteri yang terdapat dalam media tumbuh tanaman dan wadah pemeliharaan ikan akan mengubah ammonia menjadi nitrit dan nitrat. Pada tanaman, nitrat berfungsi sebagai nutrisi. Air yang kaya nutrisi dari wadah pemeliharaan disalurkan kepada tanaman, kemudian dimanfaatkan sebagai hara. Oleh karena itu penggunaan teknologi budidaya akuaponik diharapkan mampu memperbaiki kualitas air pada budidaya ikan dengan kepadatan tinggi sehingga dapat mengurangi tingkat kematian ikan. 
Berdasarkan latar belakang di atas maka dapat dirumuskan permasalahan sebagai berikut :

1. Bagaimana pengaruh sistem akuaponik untuk meningkatkan kelangsungan hidup benih ikan patin yang maksimal.

2. Berapakah kepadatan optimum tanaman air pada pemeliharaan ikan patin dengan menggunakan sistem akuaponik sehingga menghasilkan kelangsungan hidup ikan tertinggi.

Asumsi yang digunakan dalam penelitian ini bahwa kepadatan tanaman air yang optimal pada sistem akuaponik akan dapat mendukung kelangsungan hidup ikan menjadi lebih tinggi. Sedangkan tujuan dari penelitian ini adalah untuk mengetahui kepadatan optimum tanaman air untuk pemeliharaan ikan patin $(P$. hypophthalmus) pada sistem akuaponik agar dapat menghasilkan kelangsungan hidup ikan yang tinggi.

\section{METODOLOGI PENELITIAN}

Penelitian ini dilaksanakan pada bulan Maret sampai bulan Juni tahun 2018 di Balai Benih Ikan Daerah Telanaipura Provinsi Jambi.

Adapun alat yang digunakan dalam pelaksanaan penelitian ini antara lain : akuarium, pompa air, blower, serok halus, pipa paralon, keran air, literan air, baskom, selang sifon, alat pengukur kualitas air, timbangan digital, alat tulis, kamera digital, mistar, genset, akuaponik set.

Ikan uji yang digunakan adalah benih ikan patin ( $P$. hypophthalmus) yang digunakan dalam penelitian ini memiliki panjang 1 (satu) inch yang berasal dari pemijahan secara alami di Balai Benih Ikan Daerah Provinsi Jambi. Jumlah benih yang digunakan sebanyak 1800 ekor dengan kepadatan 3 ekor/liter.

Penelitian yang dilakukan menggunakan rancangan lingkungan Rancangan Acak Lengkap (RAL) dengan 4 (empat) perlakuan dan 3 (tiga) ulangan, masing masing perlakuan tersebut adalah :

1. Perlakuan A : 5 batang/lubang

2. Perlakuan B : 10 batang/lubang

3. Perlakuan $\mathrm{C}: 15$ batang/lubang

4. Perlakuan D : 20 batang/lubang

Tanaman air yang digunakan dalam penelitian ini sebanyak 150 batang. Tanaman yang digunakan disemai dalam media persemaian dan setelah tumbuh dipindahkan ke dalam lubang yang telah disiapkan pada sistem akuaponik.

Tanaman air yang telah siap tanam dimasukkan ke dalam lubang pada sistem akuaponik sesuai dengan kepadatan pada perlakuan. Kemudian benih ikan patin ( $P$. hypophthalmus), dimasukkan ke dalam akuarium sistem akuaponik dengan jumlah volume air pada masing-masing akuarium sebanyak 50 liter, kepadatan ikan sebanyak 3 ekor/liter. Ikan uji diberikan pakan pellet 3 (tiga) kali sehari dengan menggunakan metode adlibitum.

Pada masa pemeliharaan dengan sistem akuaponik ini tidak dilakukan penyiphonan maupun pergantian air karena justru feses ikan diperlukan untuk sumber hara tanaman yang dipelihara. Pada akhir penelitian akan dilakukan perhitungan kelangsungan hidup ikan uji. Adapun rumus yang digunakan untuk menghitung Survival Rate menurut Effendi (1979) adalah: 


$$
\mathrm{SR}=\frac{N t}{N o} \times 100 \%
$$

Keterangan :

SR = Kelangsungan Hidup (\% )

$\mathrm{Nt} \quad=$ Jumlah ikan yang hidup pada akhir pemeliharaan (ekor)

No $\quad=$ Jumlah ikan yang hidup pada awal pemeliharaan (ekor).

Pengukuran kualitas air yang dilakukan sebanyak 2 kali yaitu pada awal dan akhir penelitian. Pengecekan kualitas air akan dilakukan di Laboratorium Fakultas Pertanian Universitas Batanghari Jambi.

Data yang telah diperoleh kemudian ditabulasi dan dianalisis sesuai dengan tujuan penelitian. Data parameter derajat kelangsungan hidup, dianalisis menggunakan analisis ragam (ANOVA) pada selang kepercayaan 95\%.

\section{HASIL DAN PEMBAHASAN}

Berdasarkan hasil penelitian kepadatan tanaman air pada pemeliharaan benih ikan patin siam (Pangasianodon hypopthalmus F) dengan sistem akuaponik selama 30 hari, didapatkan perbedaan tingkat kelangsungan hidup (SR), dan kualitas air pada setiap perlakuan. Hasil rata - rata dari masing - masing parameter yang diuji dalam penelitian tersebut dapat dilihat pada Tabel 3 berikut ini.

Tabel 3. Parameter produksi ikan patin siam dengan tingakat kepadatan benih yang berbeda dengan sistem akuaponik

\begin{tabular}{|c|c|c|c|c|c|}
\hline \multirow{2}{*}{ NO. } & \multirow{2}{*}{ Parameter } & \multicolumn{4}{|c|}{ Perlakuan } \\
\hline & & A & B & $\mathbf{C}$ & D \\
\hline 1. & Kelangsungan Hidup (\%) & $43,64^{\mathrm{a}}$ & $49,20^{\mathrm{a}}$ & $52,65^{\mathrm{a}}$ & $84,68^{\mathrm{b}}$ \\
\hline
\end{tabular}

$\overline{\text { Keterangan : Angka - angka yang diikuti oleh huruf yang berbeda menunjukkan }}$ perlakuan berbeda nyata pada Uji Tuckey taraf $5 \%$.

Berdasarkan data pada Tabel 3 di atas terlihat bahwa kepadatan tanaman air yang berbeda pada pemeliharaan benih ikan patin dengan sistem akuaponik sangat memberikan pengaruh yang nyata terhadap tingkat kelangsungan hidup ikan patin siam ( $P$. hypopthalmus, F). Jumlah rata-rata tingkat kelangsungan hidup dari masing-masing perlakuan disajikan dalam bentuk diagram batang pada gambar 3 . 

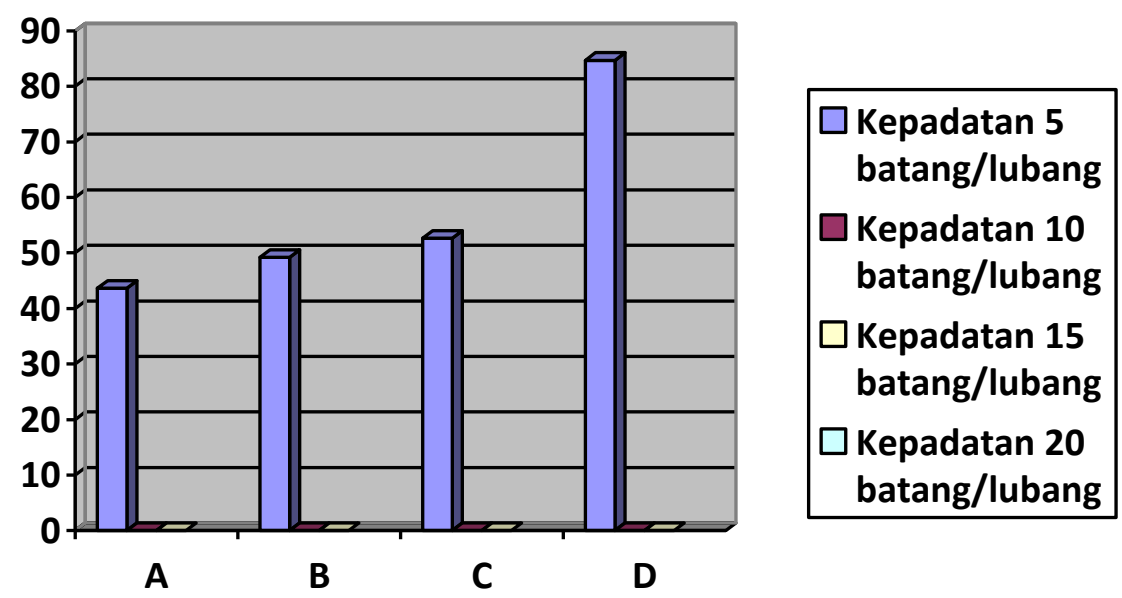

\section{Gambar 3. Rata-rata tingkat kelangsungan hidup ikan patin siam}

Pada Gambar 3 menunjukkan bahwa pada perlakuan A (kepadatan 5 batang/lubang), memberikan rata - rata tingkat kelangsungan hidup benih ikan patin siam ( $P$. hypopthalmus, F) paling rendah dengan persentase $43,64 \%$, kemudian diikuti oleh perlakuan B (kepadatan 10 batang/lubang) dengan persentase tingkat kelangsungan hidup sebesar 49,20\%, dilanjutkan dengan perlakuan $\mathrm{C}$ (kepadatan 15 batang/lubang) dengan persentase tingkat kelangsungan hidup sebesar $49,20 \%$ dan perlakuan D (kepadatan 20 batang/lubang) dengan persentase tingkat kelangsungan hidup sebesar 84,68\%. Berdasarkan analisis sidik ragam pemeliharaan benih ikan patin siam $(P$. hypopthalmus, F) dengan kepadatan tanaman air yang berbeda dengan sistem akuaponik berpengaruh nyata terhadap kelangsungan hidup benih ikan patin siam (P. hypopthalmus, F) $(\mathrm{P}<0,05)$ (Tabel 3).

Mortalitas adalah kematian yang terjadi pada suatu populasi organisme yang dapat menyebabkan turunnya jumlah populasi (Effendie, 1997). Jika diperoleh nilai SR yang tinggi maka kegiatan budidaya tersebut dapat dikatakan berhasil dan begitu juga sebaliknya. Kelangsungan hidup dipengaruhi oleh dua faktor yaitu faktor dari dalam ikan itu sendiri dan faktor dari lingkungan luar. Faktor dari dalam diantaranya umur ikan, ukuran dan kemampuan ikan beradaptasi dengan lingkungan, sedangkan faktor dari luar meliputi kondisi fisik-kimia dan media biologi, ketersediaan makanan, kompetisi antar ikan dalam mendapatkan makanan apabila jumlah makanan dalam media pemeliharaan kurang mencukupi, serta proses penanganan ikan yang kurang baik (Royce, 1972).

Pada perhitungan ANOVA tingkat Survival Rate menghasilkan perbedaan yang nyata pada setiap perlakuan. Hal ini disebabkan Pada kondisi media pemeliharaan dengan padat tebar yang tinggi, kualitas air menjadi semakin cepat buruk. Kandungan ammonia hasil metabolisme yang meningkat dapat menyebabkan gangguan yang bersifat fisiologis dan memicu stress pada ikan (Boyd, 1990). Stres pada ikan mengakibatkan turunnya daya tahan tubuh dan menurunnya nafsu makan sampai mengakibatkan terjadinya kematian (Effendi, 2003). 
Pada perlakuan D (20 batang/lubang) memiliki tingkat Survival Rate yang paling tinggi dan pada perlakuan A (5 batang/lubang) memiliki tingkat Survival Rate terendah yang disebabkan oleh kualitas air yang terbentuk karena perbedaan kepadatan pada volume akuarium pemeliharaan yang seragam. Aktivitas budidaya ikan tidak terlepas dari limbah yang dihasilkan, terutama dari sisa pakan, feses, dan hasil aktivitas metabolisme ikan. Penyebab rendahnya SR pada perlakuan B, $\mathrm{C}$ dan $\mathrm{D}$ diduga disebabkan oleh kualitas air yang semakin hari semakin menurun, sebab pada penelitian ini tidak dilakukan pergantian air selama masa pemeliharaan. Penurunan kualitas air media pemeliharaan ikan dapat diakibatkan oleh sisa pakan dan kotoran ikan yang mengendap di dasar perairan sehingga mengakibatkan naiknya kandungan amonia di dalam air.

Pada sistem budidaya tanpa pergantian air (zero water exchange), konsentrasi limbah budidaya seperti amonia (NH3), nitrit (NO2), dan karbon dioksida $\mathrm{CO} 2$ akan meningkat sangat cepat dan bersifat toksik bagi organisme budidaya (Surawidjaja, 2006 dalam Wijaya dkk, 2014). Nugroho dkk (2012) menambahkan, kepadatan atau kerapatan tebar benih ikan yang dibudidayakan harus disesuaikan dengan standar atau tingkatan budidaya. Dari hasil penelitian menunjukkan bahwa pada sistem akuaponik, perbedaan kepadatan tanaman air berpengaruh terhadap tingkat kelangsungan hidup benih ikan patin siam, fungsi sistem akuaponik mampu menunjang kegiatan pendederan sebagaimana standar sistem budidaya yang baik (CBIB). Peningkatan kepadatan tanaman menyebabkan peningkatan tingkat kelangsungan hidup benih ikan patin.

\section{KESIMPULAN}

Kepadatan tanaman air yang berbeda dengan sistem akuaponik pada pemeliharaan ikan patin siam ( $P$. hypopthalmus, F) menghasilkan tingkat kelangsungan hidup yang berbeda nyata dimana perlakuan D (20 batang tanaman/lubang) merupakan perlakuan yang terbaik dengan tingkat kelangsungan hidup tertinggi sebesar $84,68 \%$.

\section{DAFTAR PUSTAKA}

Barus,T.A. 2002. Pengantar Limnologi. Universitas Sumatera Utara. Medan.

Breet, J.R. 1979. Environmental factors and growth. In: W.S. Hoar; O.J. Randal and J.R. Breet (Edotors). Fish Physiology, Vol, VIII. New York: Academic Press, hal. 599-675.

Boyd. 1990. Water Quality in Ponds for Aquaculture, Birmingham Publishing Co., Birmingham, Alabama, USA.

Chou, L.M. 1994. Growth of Hybrid Catfhishes Under Different Supplemental Diets. The Third Asian Fishes Forum. Asian Fisheries Society, Manila, Philippines. pp. 633-636..

[DJPB] Direktorat Jenderal Perikanan Budidaya. 2011. Usaha budidaya lele dan gurami saat ini. http://www.perikanan-budidaya.kkp.go.id [15 Mei 2011].

Donk, H. 2015. Enam Model Akuaponik Untuk Lahan Sempit . Fokus Tanaman . //Blogspot.com

Effendi. H. 2000. Telaah Kualitas Air. Jurusan Manajemen Sumber Daya Peraiaran. Fakultas Perikanan Dan Ilmu Kelautan. IPB. 
Forteath, N., Wee, L. and Frith, M., (1993), Water Quality, in P. Hart and O'Sullivan (eds) Recirculation System : Design, Construction and Management, University of Tasmania at Launceston, Australia.

Madinawati. N.S dan Yoel. 2011. Pemberian pakan yang berbeda terhadap pertumbuhan dan kelangsungan hidup benih ikan lele dumbo (Clarias gariepinus). Media Litbang Sulteng.

Rukmana, H.R. 2003. Budidaya dan Pascapanen Lele Dumbo. CV. Aneka Ilmu Anggota IKAPI. Semarang.

Saanin, H. 1968. Taksonomi dan Kunci Identifikasi Ikan Jilid I dan II. Bandung: Bina Cipta.

Subandiyono, Nisrinah Dan Elfitasari. 2013. Pengaruh Penggunaan Bromelin Terhadap Tingkat Pemanfaatan Protein Pakan Dan Pertumbuhan Lele Dumbo (Clarias Gariepinus).

Urbanina. 2016. Sistem Akuaponik Kelebihan Dan Kekurangan . //blogspot.com

Yamagata Y, Niwa M. 1982. Acute and choronic toxicity of ammonia to ell Anguilla japonica. Bull.Jap. Soc. Sci.Fish. 48 (2), 171-176

Zonneveld. N, E. A. Huisman, J. H. Boon. (1991). Prinsip-prinsip budidaya ikan. Gramedia Pustaka Umum. Jakarta 